\title{
Distribution of micro-organisms along a transect in the South-East Pacific Ocean (BIOSOPE cruise) using epifluorescence microscopy
}

\author{
S. Masquelier and D. Vaulot \\ Station Biologique de Roscoff, UMR 7144, CNRS et Université Pierre et Marie Curie, Place G. Tessier, 29682, Roscoff, \\ France
}

Received: 6 July 2007 - Published in Biogeosciences Discuss.: 7 August 2007

Revised: 18 January 2008 - Accepted: 1 February 2008 - Published: 4 March 2008

\begin{abstract}
The distribution of selected groups of microorganisms was analyzed along a South-East Pacific Ocean transect sampled during the BIOSOPE cruise in 2004. The transect could be divided into four regions of contrasted trophic status: a High Nutrient Low Chlorophyll (HNLC) region (mesotrophic) near the equator, the South-East Pacific Ocean gyre (hyper-oligotrophic), a transition region between the gyre and the coast of South America (moderately oligotrophic), and the Chile upwelling (eutrophic). The abundance of phycoerythrin containing picocyanobacteria (PE picocyanobacteria), autotrophic and heterotrophic eukaryotes (classified into different size ranges), dinoflagellates, and ciliates was determined by epifluorescence microscopy after DAPI staining. Despite some apparent loss of cells due to sample storage, distribution patterns were broadly similar to those obtained by flow cytometry for PE picocyanobacteria and picoeukaryotes. All populations reached a maximum in the Chile upwelling and a minimum near the centre of the gyre. The maximum abundance of PE picocyanobacteria was $7010^{3}$ cell mL $^{-1}$. Abundance of autotrophic eukaryotes and dinoflagellates reached $24.510^{3}$ and 20 cell $\mathrm{mL}^{-1}$, respectively. We observed a shift in the size distribution of autotrophic eukaryotes from $2-5 \mu \mathrm{m}$ in eutrophic and mesotrophic regions to less than $2 \mu \mathrm{m}$ in the central region. The contribution of autotrophic eukaryotes to total eukaryotes was the lowest in the central gyre. Maximum concentration of ciliates $\left(18\right.$ cell $\left.\mathrm{mL}^{-1}\right)$ also occurred in the Chile upwelling, but, in contrast to the other groups, their abundance was very low in the HNLC zone and near the Marquesas Islands. Two key findings of this work that could not have been observed with other techniques are the high percentage of PE picocyanobacteria forming colonies in the HLNC region and the observation of numerous dinoflagellates with bright green autofluorescence.
\end{abstract}

Correspondence to: D. Vaulot (vaulot@sb-roscoff.fr)

\section{Introduction}

Unicellular picoplanktonic prokaryotes and eukaryotes less than $2 \mu \mathrm{m}$ in size (Sieburth et al., 1978) are found in marine ecosystems at concentrations ranging from $10^{2}$ to $10^{5}$ and $10^{2}$ to $10^{4}$ cell $\mathrm{mL}^{-1}$, respectively. They play a fundamental role (Azam et al., 1983; Sherr and Sherr, 2000), in particular, in oligotrophic waters (Hagström et al., 1988; Marañón et al., 2001) where their small size associated to the reduced diffusion boundary layer and large surface area per unit volume are an advantage to acquire nutrients (Raven, 1998). The photosynthetic component of picoplankton, i.e. Prochlorococcus and Synechococcus cyanobacteria and picoeukaryotic algae, are important contributors to the microbial community of the euphotic zone in many marine environments (Mackey et al., 2002; Pérez et al., 2006). Heterotrophic protists play a pivotal role in mediating organic flux to higher trophic levels in pelagic ecosystems (Azam et al., 1983; Fenchel, 1982; Hagström et al., 1988). Among the heterotrophic protists, ciliates and dinoflagellates are important grazers of picoplankton (Christaki et al., 2002).

In the Pacific Ocean, picoplankton has been analyzed both in the Equatorial region and the North gyre (e.g. Campbell et al., 1997; Mackey et al., 2002) but not in the South gyre. The latter is the most oligotrophic environment of the world oceans based on SeaWifs imagery which provides estimates of average surface chlorophyll $a$ concentrations down to $0.02 \mathrm{mg} \mathrm{m}^{-3}$ (Morel et al., 2007). The BIOSOPE (Biogeochemistry and Optics South Pacific Experiment) cruise explored this region sailing from the Marquesas Islands to the coast of Chile. Along this transect, a gradient in trophic conditions was encountered, from hyper-oligotrophic (gyre) to very eutrophic waters (Chile upwelling). The present study relied on epifluorescence microscopy to assess the distribution in this region of phycoerythrin containing picocyanobacteria (called PE picocyanobacteria throughout the paper), autotrophic and heterotrophic eukaryotes (in particular dinoflagellates and ciliates). In contrast to faster

Published by Copernicus Publications on behalf of the European Geosciences Union. 


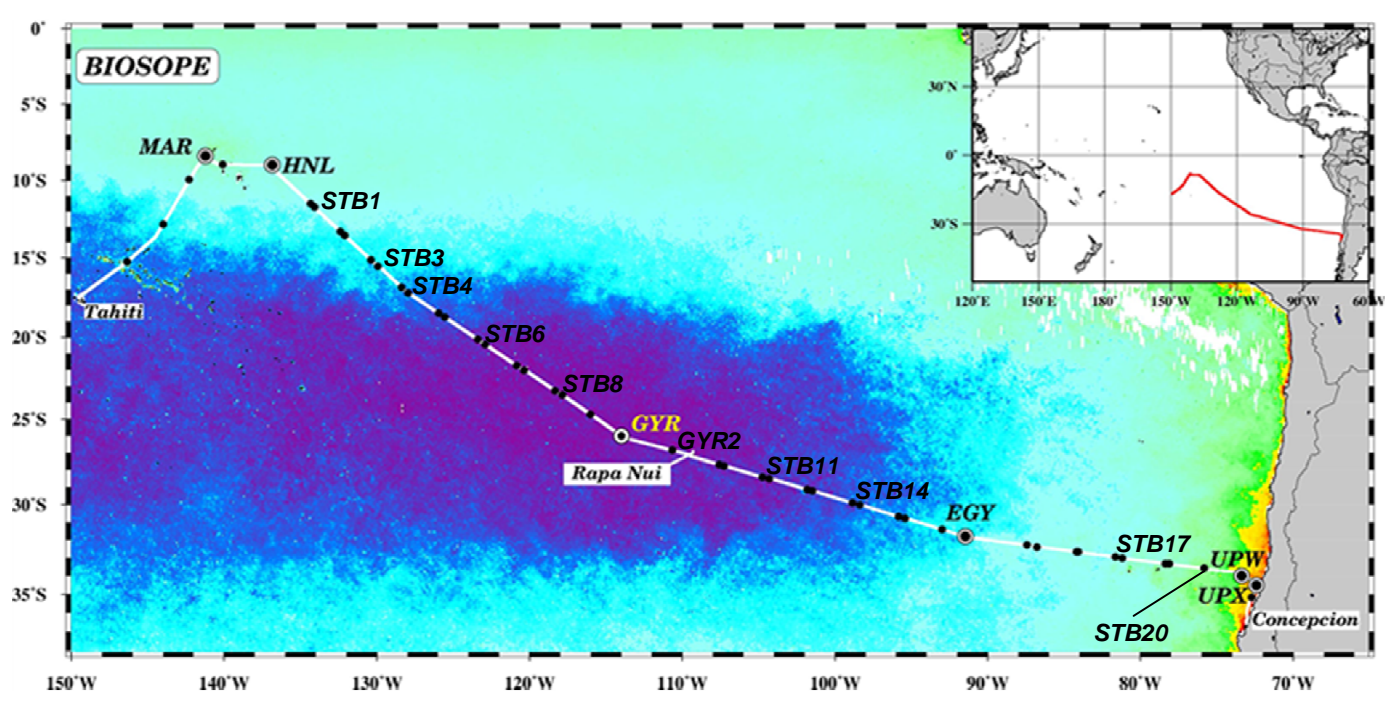

Fig. 1. Map of the BIOSOPE cruise track superimposed on a SeaWiFS ocean colour composite, dark purple indicating extremely low values $\left(0.018 \mathrm{mg} \mathrm{m}^{-3}\right)$ of total chlorophyll $a$. Figure modified from Claustre et al. (2007). Stations analyzed by DAPI staining are labelled.

Table 1. Concentrations of the different populations enumerated in the present study. Values are averages for the six depths sampled at each station.

\begin{tabular}{|c|c|c|c|c|c|c|c|c|c|c|}
\hline Station & Latitude-Longitude & $\begin{array}{l}\text { Picocyanobacteria } \\
\text { containing } \\
\text { phycoerythrin } \\
\text { mL }^{-1}\end{array}$ & $\begin{array}{l}\text { Total } \\
\text { eukaryotes } \\
\mathbf{m L} \mathbf{L}^{-1}\end{array}$ & $\begin{array}{l}\text { Autotrophic } \\
\text { eukaryotes } \\
\mathbf{m L}^{-1}\end{array}$ & $\begin{array}{l}\text { Heterotrophic } \\
\text { eukaryotes } \\
\mathbf{m L}^{-1}\end{array}$ & $\begin{array}{l}\text { Total } \\
\text { dinoflagellates } \\
\mathbf{m L}^{-1}\end{array}$ & $\begin{array}{l}\text { Autotrophic } \\
\text { dinoflagellates } \\
\mathbf{m L}^{-1}\end{array}$ & $\begin{array}{l}\text { Heterotrophic } \\
\text { dinoflagellates } \\
\mathbf{m L}^{-1}\end{array}$ & $\begin{array}{l}\text { Green } \\
\text { dinoflagellates } \\
\mathbf{m L}^{-1}\end{array}$ & $\begin{array}{l}\text { Total } \\
\text { ciliates } \\
\mathbf{m L}^{-1}\end{array}$ \\
\hline MAR1 & $08^{\circ} 23 \mathrm{~S}-141^{\circ} 14 \mathrm{~W}$ & 3486 & 1520 & 1292 & 228 & 105 & 56 & 48 & 4.6 & $<1.5$ \\
\hline HLN1 & $09^{\circ} 00 \mathrm{~S}-136^{\circ} 51 \mathrm{~W}$ & 2818 & 2312 & 1836 & 476 & 93 & 61 & 32 & 4.2 & 3 \\
\hline STB1 & $11^{\circ} 44 \mathrm{~S}-134^{\circ} 06 \mathrm{~W}$ & 1612 & 1895 & 1165 & 730 & 111 & 62 & 50 & 4.5 & 1.5 \\
\hline STB3 & $15^{\circ} 00 \mathrm{~S}-129^{\circ} 55 \mathrm{~W}$ & 413 & 1423 & 737 & 686 & 59 & 28 & 31 & 4.2 & 3.5 \\
\hline STB4 & $17^{\circ} 13 \mathrm{~S}-127^{\circ} 58 \mathrm{~W}$ & 374 & 1267 & 736 & 531 & 57 & 26 & 32 & 7.0 & 1.5 \\
\hline STB6 & $20^{\circ} 26 \mathrm{~S}-122^{\circ} 54 \mathrm{~W}$ & 6 & 1413 & 726 & 687 & 37 & 19 & 17 & 2.2 & 1.5 \\
\hline STB8 & $23^{\circ} 32 \mathrm{~S}-117^{\circ} 52 \mathrm{~W}$ & 37 & 937 & 521 & 416 & 31 & 12 & 19 & 3.5 & 4.5 \\
\hline GYR2 & $25^{\circ} 58 \mathrm{~S}-114^{\circ} 00 \mathrm{~W}$ & 46 & 806 & 541 & 265 & 43 & 21 & 22 & 3.5 & 1.5 \\
\hline STB11 & $27^{\circ} 45 \mathrm{~S}-107^{\circ} 16 \mathrm{~W}$ & 34 & 1050 & 526 & 525 & 31 & 10 & 21 & 6.5 & $<1.5$ \\
\hline STB14 & $30^{\circ} 02 \mathrm{~S}-98^{\circ} 23 \mathrm{~W}$ & 142 & 1314 & 854 & 460 & 55 & 22 & 33 & 8.5 & 4.2 \\
\hline EGY2 & $31^{\circ} 50 \mathrm{~S}-91^{\circ} 27 \mathrm{~W}$ & 1734 & 3083 & 2481 & 602 & 82 & 47 & 35 & 6.5 & 1.9 \\
\hline STB17 & $32^{\circ} 23 \mathrm{~S}-86^{\circ} 47 \mathrm{~W}$ & 1104 & 2607 & 2086 & 521 & 94 & 46 & 48 & 12 & 5.2 \\
\hline STB20 & $33^{\circ} 21 \mathrm{~S}-78^{\circ} 06 \mathrm{~W}$ & 10726 & 1760 & 1195 & 566 & 92 & 44 & 48 & 6.7 & 3 \\
\hline UPW1 & $34^{\circ} 01 \mathrm{~S}-73^{\circ} 21 \mathrm{~W}$ & 40548 & 3396 & 2526 & 870 & 122 & 63 & 59 & 15 & 10 \\
\hline UPX2 & $34^{\circ} 37 \mathrm{~S}-72^{\circ} 27 \mathrm{~W}$ & 18548 & 14088 & 12211 & 1877 & 151 & 47 & 104 & 38 & 6.6 \\
\hline
\end{tabular}

enumeration techniques such as flow cytometry, epifluorescence microscopy allows (1) to discriminate specific group of organisms such as dinoflagellates, (2) to recognize cell organization such as colonies, and (3) to regroup organisms into size classes. We attempted to relate the distribution of the different types of organisms to oceanographic conditions.

\section{Material and methods}

\subsection{Oceanographic context}

The BIOSOPE cruise took place on board the French NO "l'Atalante" in the South-East Pacific Ocean from 26th October to 11th December 2004 (Fig. 1). The transect inves- tigated extended from the Marquesas Islands (South Pacific Tropical Waters; SPTW) to the coast of Chile, through the Eastern South Pacific Central Waters (ESPCW) which include the centre of the Pacific gyre (Claustre et al., 2008). The transect can be divided into four contrasted trophic zones (from West to East): a High Nutrient Low Chlorophyll (HNLC) zone (mesotrophic) near the equator, the South-East Pacific gyre (hyper-oligotrophic) proper, the transition zone between the gyre and the coastal region (moderately oligotrophic), and the Chile upwelling (very eutrophic). In the hyper oligotrophic zone, nitrate concentrations were nearly undetectable between the surface and $150-200 \mathrm{~m}$ and remained very low $(\sim 2.5 \mu \mathrm{M})$ below this depth (Fig. 2 in Raimbault et al., 2007). Nitrate concentrations were higher in the HNLC zone and maximum in the Chile upwelling 


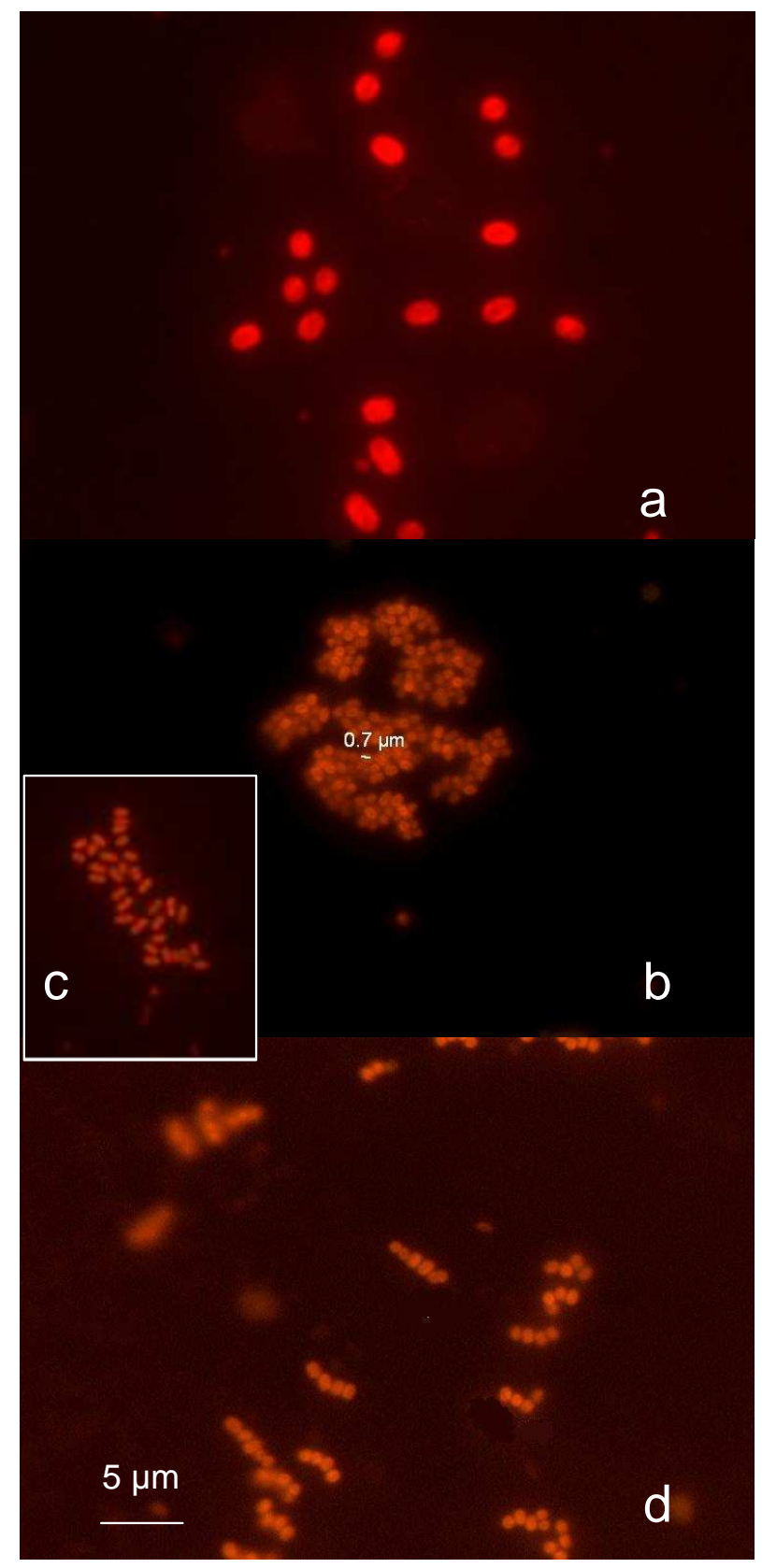

Fig. 2. Pictures of single (a), and colonial PE picocyanobacteria (bd). Colony of more than 100 cells (b). Colony of 20-30 cells (c). Chain forming cells (d). Pictures taken under green light excitation on samples of stations MAR1 at $80 \mathrm{~m}$ (a), MAR1 at $40 \mathrm{~m}$ (b), HNL1 at $60 \mathrm{~m}(\mathrm{c})$, and STB3 at $60 \mathrm{~m}(\mathrm{~d})$.

(Fig. 2 in Raimbault et al., 2007). Phosphate was apparently never a limiting factor (Fig. 2 in Raimbault et al., 2007).

\subsection{DAPI staining and epifluorescence microscopy}

Fifteen stations (Fig. 1 and Table 1) were sampled at six depths with a conductivity-temperature-depth (CTD) rosette

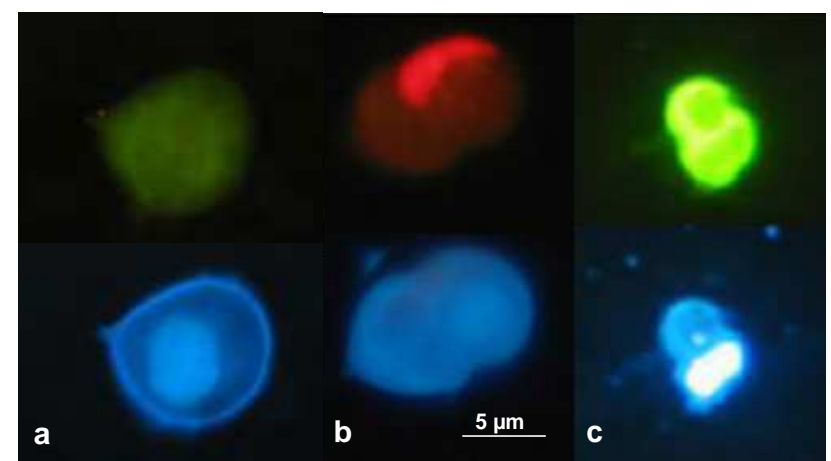

Fig. 3. Heterotrophic (a), autotrophic (b), and green fluorescing dinoflagellates (c) observed under blue light excitation (top) and UV light excitation (bottom). Pictures taken at stations STB3 $(20 \mathrm{~m})$, UPW and STB7 (5 m), respectively.

system equipped with $12 \mathrm{~L}$ Niskin bottles. In general, two samples were collected in the surface layer, three around the chlorophyll maximum and one below. Water was pre-filtered through a $200 \mu \mathrm{m}$ mesh to remove zooplankton, large phytoplankton, and particles before further filtrations.

Water samples $(100 \mathrm{~mL})$ were fixed with glutaraldehyde ( $0.25 \%$ final concentration) and filtered through $0.8 \mu \mathrm{m}$ pore size filters. This porosity was selected to avoid high densities of bacteria on the filter which would have rendered visualisation of the larger and less dense eukaryotes more difficult. Samples were stained with 4'6-diamidino-2-phenylindole (DAPI, $5 \mu \mathrm{g} \mathrm{mL}^{-1}$ final concentration) (Porter and Feig, 1980) and stored at $-20^{\circ} \mathrm{C}$ for a minimum of 12 months before counting. Counts were performed with an Olympus BX51 epifluorescence microscope (Olympus Optical CO, Tokyo, Japan) equipped with a mercury light source and an $\mathrm{x} 100$ UVFL objective. Pictures of dinoflagellates were taken on board the ship on the freshly prepared slides using a $\mathrm{BH} 2$ Olympus microscope with an $\mathrm{x} 40$ objective and a Canon G5 digital camera. Pictures of PE containing picocyanobacteria were taken in the laboratory on the BX51 Olympus microscope with a Spot RT-slider camera (Diagnostics Instruments, Sterling Heights, MI).

Prochlorococcus cannot be counted reliably by epifluorescence microscopy because of their small size and rapidly fading fluorescence. Therefore, only isolated and colonial PE picocyanobacteria (Fig. 2) were counted based on the orange fluorescence of phycoerythrin excited under green light $(530-550 \mathrm{~nm})$. DAPI staining allowed us to discriminate eukaryotic from prokaryotic organisms. Under UV light $(360 / 420 \mathrm{~nm})$, eukaryotic cell nucleus appeared as a separate blue organelle, while for prokaryotes, no nucleus was visible and cells appeared uniformly stained. The red fluorescence of chlorophyll under blue light $(490 / 515 \mathrm{~nm})$ allowed us to discriminate autotrophic (photosynthetic) from heterotrophic eukaryotes. However, it was not possible to distinguish truly autotrophic organisms from organisms that had ingested 

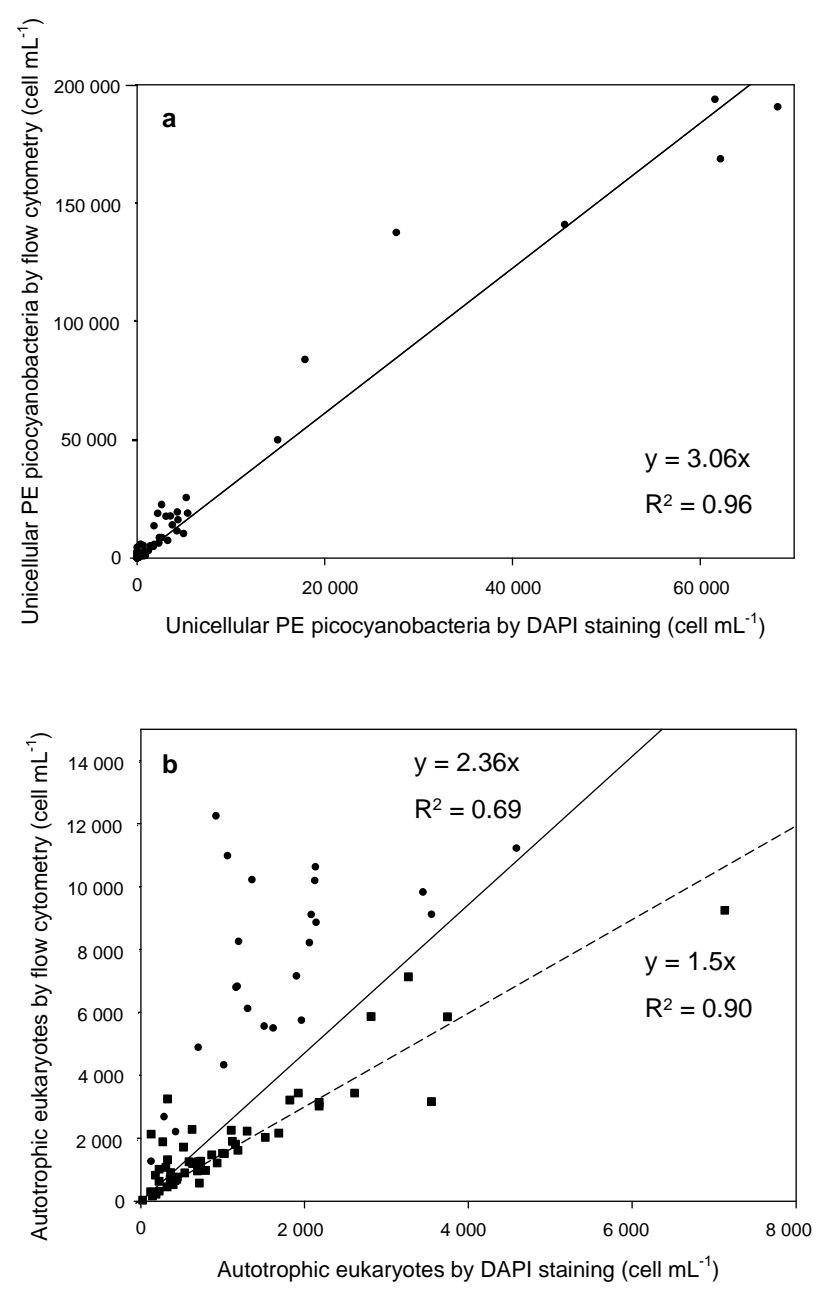

Fig. 4. Relationship between abundance $\left(\right.$ cell $\left.\mathrm{mL}^{-1}\right)$ measured by flow cytometry (Grob et al., 2007) and estimated by DAPI counting for unicellular PE picocyanobacteria (a), and autotrophic eukaryotes (b). In panel (b) circles correspond to data from surface to 40-60 m depth depending on samples. Squares correspond to data from $40-60 \mathrm{~m}$ depth to $300 \mathrm{~m}$ depth. (a) $R^{2}=0.96, \mathrm{n}=80$; (b) Solid line takes into account all data (circles and squares); $R^{2}=0.69 n=80$. Dashed line takes into account only squares; $R^{2}=0.90, \mathrm{n}=56$.

chlorophyll-containing cells. Ten fields and a minimum of 100 cells were counted per slide. Eukaryotes were classified according to three diameter ranges: (i) smaller than $2 \mu \mathrm{m}$, (ii) between $2 \mu \mathrm{m}$ and $5 \mu \mathrm{m}$, (iii) larger than $5 \mu \mathrm{m}$. Among eukaryotes larger than $5 \mu \mathrm{m}$, ciliates and dinoflagellates were counted separately. Dinoflagellates were discriminated by their shape, their size (between $5 \mu \mathrm{m}$ and $100 \mu \mathrm{m}$ ), and the presence of a nucleus with condensed chromatin. Autotrophic and heterotrophic dinoflagellates were discriminated according to the red fluorescence of chlorophyll under blue light of the former (Figs. 3a and b). Among heterotrophic dinoflagellates, some were characterized by an intense green fluorescence under blue light (Fig. 3c), as reported previously (Shapiro et al., 1989), and counted sepa- rately. Ciliates were discriminated by their shape, their size (between $20 \mu \mathrm{m}$ and $100 \mu \mathrm{m}$ ), and the presence of cilia and multiple nuclei. No distinction between different types of ciliates was attempted. Because of their low abundance, 50 fields per slide were counted for dinoflagellates and ciliates such that the minimum concentration detectable was 1.5 cell $\mathrm{mL}^{-1}$.

\subsection{Data representation}

Contour maps showing the distributions of the different populations were drawn using the Ocean Data View software (Schlitzer, 2003) with averaging VG gridding length-scales of 100 for both $\mathrm{X}$ and Y.

\section{Results}

\subsection{Comparison between microscopy and flow cytometry}

In order to validate our microscopy counts, we compared them to counts of Synechococcus cyanobacteria and photosynthetic eukaryotes done by flow cytometry (Grob et al., 2007) at the same stations (Fig. 4). There was a relatively good correlation between the two methods, such that global distribution trends were identical. However, slopes were significantly larger than one indicating that microscopy was underestimating the actual concentrations. For PE picocyanobacteria $\left(R^{2}=0.96 ; \mathrm{n}=80\right)$, abundance found by microscopy was 3 times lower than measured by flow cytometry (Fig. 4a). For photosynthetic eukaryotes, the correlation was moderate $\left(\mathrm{R}^{2}=0.69 ; \mathrm{n}=80\right)$ when all the data were considered, although the slope was lower than for cyanobacteria (Fig. 4b). When only data below 40-60 m were included, the correlation was significantly better $\left(\mathrm{R}^{2}=0.90 ; \mathrm{n}=56\right)$ and the slope less pronounced.

\subsection{PE picocyanobacteria}

In surface, abundance of PE picocyanobacteria (Fig. 5a) reached a maximum $\left(7010^{3}\right.$ cell $\left.\mathrm{mL}^{-1}\right)$ near the coast of Chile (station UPW1) and a minimum (less than 500 cell $\mathrm{mL}^{-1}$ ) in the middle of the South-East Pacific gyre. Their abundance increased again near the Marquesas Islands. In the vertical dimension, abundance decreased slightly down to circa $100 \mathrm{~m}$ and cells quickly disappeared below (Fig. 5a). Interestingly, a large fraction of the PE picocyanobacteria belonged to colonial forms in the vicinity of the Marquesas Islands and in the HNLC zone (Fig. 5b). In this region, this fraction could reach up to $50 \%$ near the surface and 5 to $10 \%$ between 25 and $100 \mathrm{~m}$, while it dropped below 5\% almost everywhere else. Three types of colony could be observed (Fig. 2): (i) groups of 20-30 cells, (ii) groups of more than 100 cells, (iii) short chains. None of these forms seemed to be preferentially observed in any given region. 

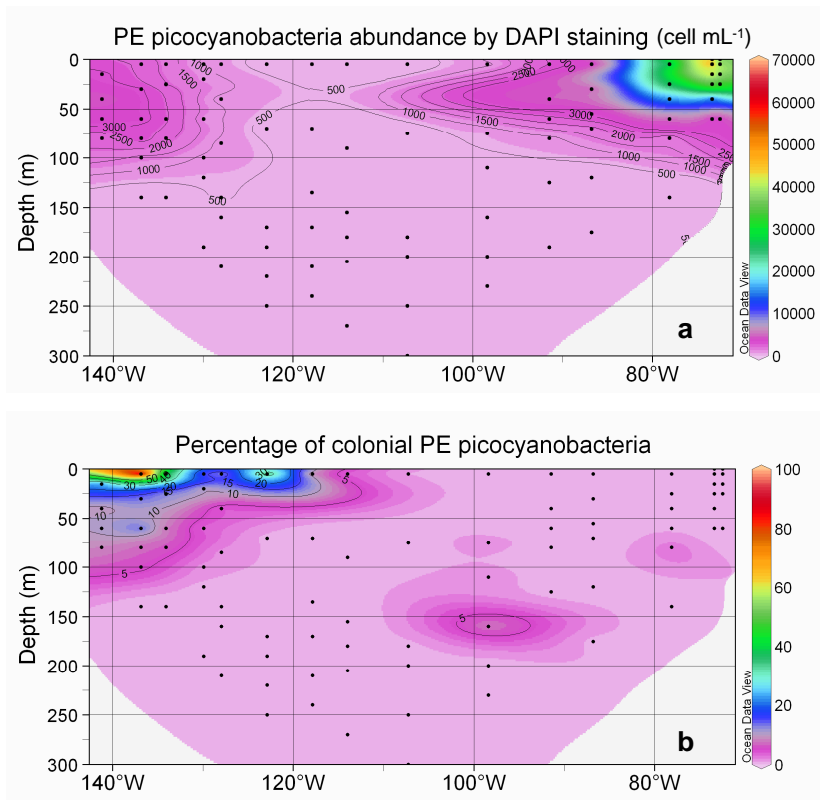

Fig. 5. Abundance obtained by DAPI counting for unicellular PE picocyanobacteria (cell $\mathrm{mL}^{-1}$ ) (a), and percentage of unicellular PE picocyanobacteria in colony (b). Black dots correspond to samples analysed. Contour plots generated with the software Ocean Data View.

\subsection{Eukaryotes}

Maximum abundance of total eukaryotes $\left(2610^{3}\right.$ cell $\mathrm{mL}^{-1}$ ) occurred in the Chile upwelling near the surface (station UPX2, $25 \mathrm{~m})$ and minimum $\left(276\right.$ cell $\left.\mathrm{mL}^{-1}\right)$ in the gyre at depth (station GYR2, 270 m) (Fig. 6a). In the surface layer, abundance was minimal in the center of the gyre and increased both eastward and westward. The maxima of total eukaryotes coincided roughly with the depth of chlorophyll maximum (DCM, see Fig. 3 in Raimbault et al., 2007). Below $200 \mathrm{~m}$, concentrations were always lower than 1000 cell $\mathrm{mL}^{-1}$. The distributions of total eukaryotes and autotrophic eukaryotes were very similar with a maximum in the Chile upwelling and a minimum in the surface of the gyre (Fig. 6b). These similar distributions were a mere consequence of the fact that autotrophic eukaryotes were much more abundant than heterotrophic ones around the DCM (Fig. 6c). The size distribution of autotrophic eukaryotes varied dramatically throughout the transect (Figs. 7 and 8): in the surface of the gyre, cells smaller than $2 \mu \mathrm{m}$ accounted for less than $10 \%$ while, they dominated $(50-70 \%)$ in the DCM of the gyre as well as east of the gyre (Fig. 7a). In the Chile upwelling (station UPX2, $25 \mathrm{~m}$ ), they accounted for up to $80 \%$ of the total eukaryotes. In contrast, their contribution was much lower in the HNLC region where larger eukaryotes between $2 \mu \mathrm{m}$ and $5 \mu \mathrm{m}$ accounted for $40 \%$ to $60 \%$ of the population (Fig. 7b). This size class was also dominant near the surface in the transition zone between the
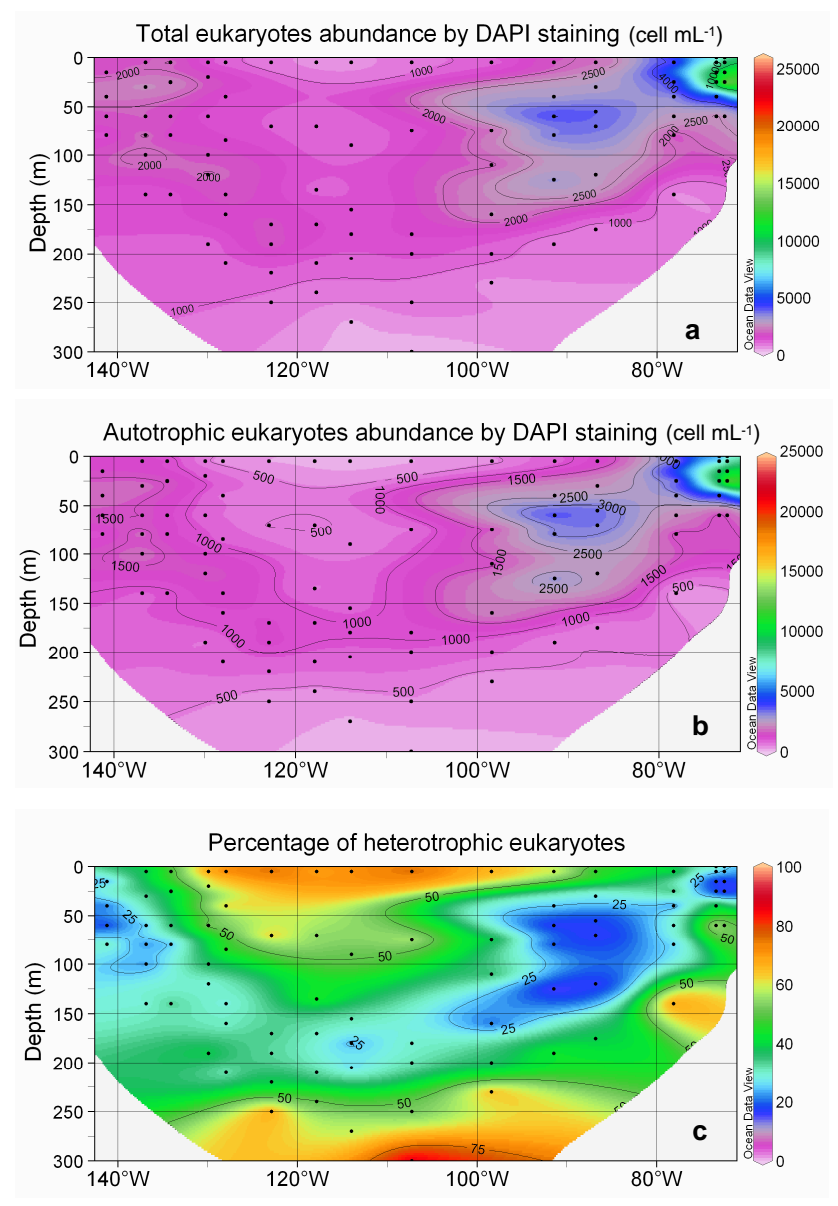

Fig. 6. Abundance obtained by DAPI counting of total eukaryotes $\left(\right.$ cell $\left.\mathrm{mL}^{-1}\right)(\mathbf{a})$, autotrophic eukaryotes $\left(\right.$ cell $\left.\mathrm{mL}^{-1}\right)(\mathbf{b})$, and percentage of heterotrophic eukaryotes in comparison with total eukaryotes (c). Legend as in Fig. 5.

gyre and the upwelling. Cells larger than $5 \mu \mathrm{m}$ accounted for less than $10 \%$ of autotrophic eukaryotes everywhere along the transect, except near the Marquesas Islands where they contributed slightly more (Fig. 7c).

The relative proportion of heterotrophic eukaryotes was the highest in the $0-50 \mathrm{~m}$ layer of the gyre $(75-80 \%)$, while in the DCM it dropped to $25 \%$ (Fig. 6c). In the DCM, cells smaller than $2 \mu \mathrm{m}$ accounted for $28 \%$ (east of the gyre) to $40 \%$ (in the gyre) of heterotrophic eukaryotes (Fig. 8). The contribution of cells between $2 \mu \mathrm{m}$ and $5 \mu \mathrm{m}$ did not vary much (about 50\%) while cells larger than $5 \mu \mathrm{m}$ accounted for up to $14 \%$ of total heterotrophic eukaryotes in the HNLC region and for about $10 \%$ elsewhere.

In the $0-100 \mathrm{~m}$ layer, dinoflagellate abundance (Fig. 9a) increased towards the HNLC region (maximum observed: 200 cell $\mathrm{mL}^{-1}$ at station STB1, 25 m) and the Chile upwelling, and decreased towards the gyre (minimum observed: 10 cell $\mathrm{mL}^{-1}$ at station GYR2, $270 \mathrm{~m}$ ). In relative terms, autotrophic dinoflagellates dominated around the 

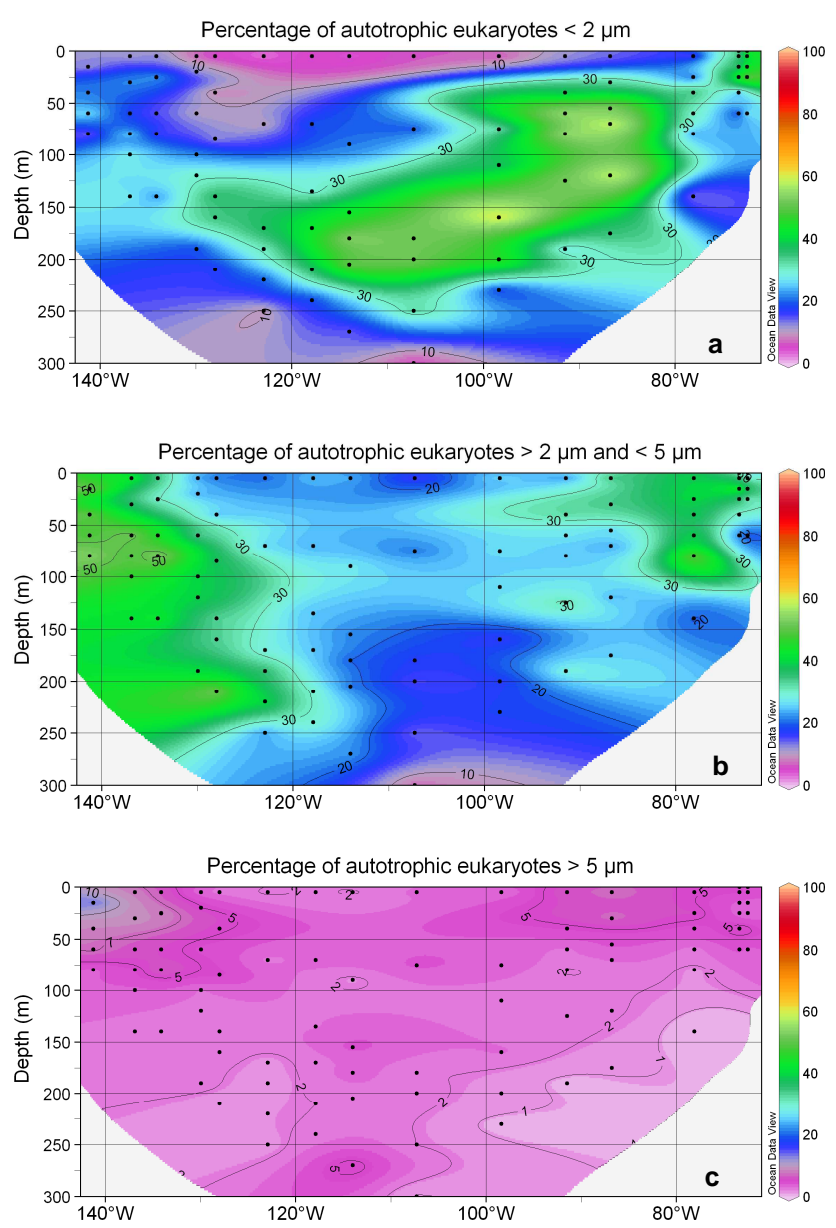

Fig. 7. Fraction of autotrophic eukaryotes smaller than $2 \mu \mathrm{m}$ (a), between $2 \mu \mathrm{m}$ and $5 \mu \mathrm{m}$ (b), and larger than $5 \mu \mathrm{m}$ (c) in comparison with the total eukaryotes. Legend as in Fig. 5.

Marquesas Islands (up to $80 \%$ of total dinoflagellates, at station STB1, $80 \mathrm{~m}$ depth) and in the Chile upwelling (70\% at station UPW1, $15 \mathrm{~m}$ depth) (Fig. 9b). The maximum of percentage of autotrophic dinoflagellates $(50 \%-80 \%)$ followed the DCM except at station STB8 where the highest percentage $(50 \%)$ occurred at $70 \mathrm{~m}$ whereas the DCM was found much below at $170 \mathrm{~m}$ (Compare Fig. $9 \mathrm{~b}$ in the present study and Fig. 3 in Raimbault et al., 2007). In the Chile upwelling, the maximum of autotrophic dinoflagellates $(50 \%$ at station UPX2 in surface and 70\% at station UPW1 at $15 \mathrm{~m}$ ) occurred above the DCM. The percentage of autotrophic dinoflagellates was the lowest $(5 \%-25 \%)$ in the surface of the gyre and below $250 \mathrm{~m}$.

Heterotrophic dinoflagellates contribution ranged from $20 \%$ to $95 \%$ of the total (Fig. 9c) and consisted mostly (75\% on average) of cells smaller than $15 \mu \mathrm{m}$ in size (data not shown). Vertical profiles showed that maximum abundances of heterotrophic dinoflagellates followed the DCM only at some stations in the gyre (STB3, STB6 and STB8, Fig. 10).

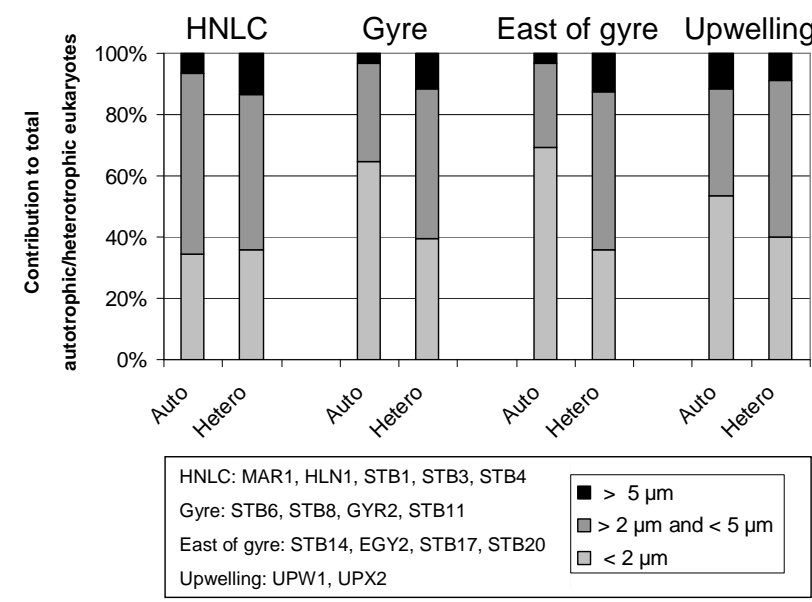

Fig. 8. Contribution of the different size classes to the abundance of autotrophic (Auto) and heterotrophic (Hetero) eukaryotes at the depth of chlorophyll maximum for the HNLC, Gyre, East of gyre and Chile upwelling regions.

At other stations, the maximum abundance of heterotrophic dinoflagellates was observed above the DCM, except in the upwelling (station UPX2) where the maximum was found below. At station EGY2 (east of gyre), the lowest concentration of heterotrophic dinoflagellates $\left(18\right.$ cell $\left.\mathrm{mL}^{-1}\right)$ occurred in the DCM.

Green fluorescing dinoflagellates (Fig. 3c) accounted for up to $50 \%$ of the heterotrophic dinoflagellates in surface east of the gyre and at depth in the Chile upwelling. They accounted for 5 to $25 \%$ of heterotrophic dinoflagellates in the HNLC zone and in surface in the Chile upwelling (Fig. 9d).

Ciliate abundance reached a maximum $\left(18\right.$ cell $\left.\mathrm{mL}^{-1}\right)$ in the Chile upwelling (station UPW1, $40 \mathrm{~m}$ depth) and a minimum in the HNLC region (Fig. 11). Abundance increased towards the Chile upwelling and decreased towards the gyre as for most other groups. However, in contrast to most other groups, ciliates also remained quite low towards the HNLC zone and the Marquesas Islands. Vertically, at many stations, ciliate maxima corresponded to dinoflagellate minima (Fig. 10).

\section{Discussion}

Differences between abundances estimated by microscopy vs. flow cytometry observed in this study could be due to several reasons. First, some cells smaller than $0.8 \mu \mathrm{m}$ (e.g. some Synechococcus) could have passed through the $0.8 \mu \mathrm{m}$ filter used here. The loss of eukaryotic cells is however likely to be negligible since the smallest known eukaryote Ostreococcus tauri has a size of $0.8 \mu \mathrm{m}$ (Courties et al., 1994). Furthermore, according to Sherr et al. (2005), $16 \%$ of Synechococcus and only $2 \%$ of picoeukaryote cells may pass through a $1 \mu \mathrm{m}$ filter. This may explain why the slope in the Fig. 4 is 

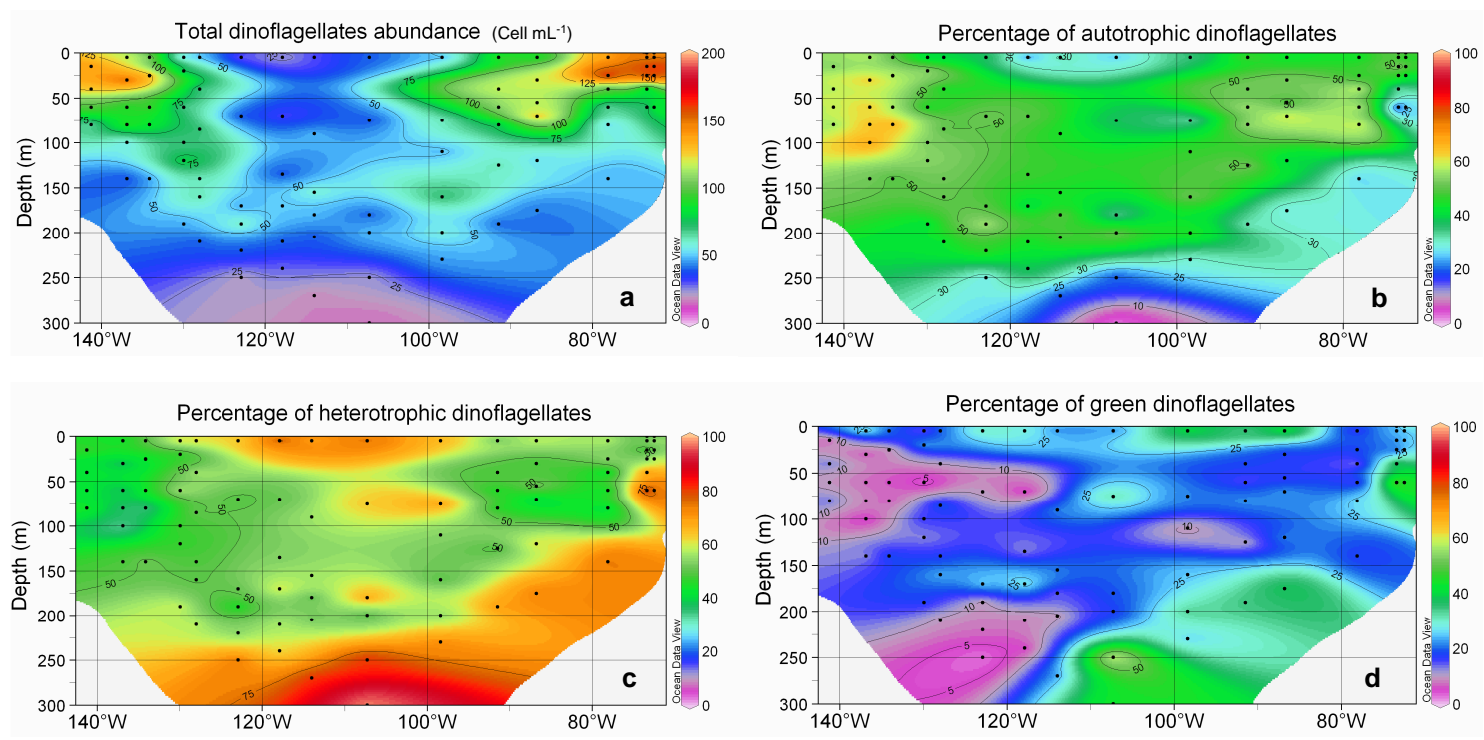

Fig. 9. Total dinoflagellates (cell $\left.\mathrm{mL}^{-1}\right)(\mathbf{a})$, percentage of autotrophic dinoflagellates over total dinoflagellates (b), percentage of heterotrophic over total dinoflagellates (c), and percentage of green dinoflagellates over total heterotrophic dinoflagellates (d). Legend as in Fig. 5.

larger for PE picocyanobacteria than for eukaryotes. Second, samples for microscopy were stored for more than a year at $-20^{\circ} \mathrm{C}$ before counting while samples for flow cytometry were analyzed fresh on board. Gundersen et al. (1996) and Putland et al. (1999) found significant losses for bacteria and for unicellular cyanobacteria after one month and three months, respectively, of sample storage at $-20{ }^{\circ} \mathrm{C}$. Third, such storage conditions may cause a degradation of chlorophyll and an underestimation of red fluorescing organisms (Chavez et al., 1990). Therefore, abundances of unicellular PE picocyanobacteria and autotrophic eukaryotes may be underestimated, while the proportion of heterotrophic eukaryotes could be higher than in the initial samples. In fact, we observed that organisms from surface samples had less intense chlorophyll fluorescence than those of deeper samples (as expected due to photoacclimation). Moreover, this fluorescence faded faster. Therefore the distinction between autotrophic and heterotrophic organisms near the surface was not always easy. This could explain the lower correlation and higher slopes between flow cytometry and epifluorescence abundances for samples above 40-60 m (Fig. 4).

The low abundance of PE picocyanobacteria in the gyre and their higher abundance in the Chile upwelling, a region rich in nutrients and characterized by mixed waters, is in agreement with many studies (for a review see Partensky et al., 1999). Interestingly, up to $50 \%$ of the PE picocyanobacteria counted by microscopy appeared to be colonial near the Marquesas Islands and in the HNLC region (Figs. 2 and 5b). Comparison with flow cytometry data showed that at least $33 \%$ of the PE picocyanobacteria were retained by the 0.8 $\mu \mathrm{m}$ filter, assuming that no cells were lost because of sam- ple fixation and conservation (Fig. 4). Therefore, colonial PE picocyanobacteria would represent at least $15 \%$ (i.e. $33 \%$ of $50 \%$ ) of all PE picocyanobacteria.

The high proportion of colonial PE picocyanobacteria near the Marquesas Islands and in the HNLC region could be due to a preference of colony-forming cyanobacteria for high nutrient waters (Paerl, 2000). However, the fact that we observed only $1 \%$ of colonial PE picocyanobacteria in the Chile upwelling seems to indicate that other factors have to be taken into account. Some cyanobacteria encountered in marine systems form colonies (Graham and Wilcox, 2000) but these are usually much larger than those we observed. It is, for example, the case for Trichodesmium that has been previously observed in the Equatorial Pacific (Capone et al., 1997). Interestingly, unicellular PE picocyanobacteria forming chains (cf. Fig. 2d) were isolated in culture from the HNLC station at $30 \mathrm{~m}$ and $100 \mathrm{~m}$ depth (Le Gall et al., 2008) but the other morphotypes observed in the field were not obtained. Since there was some evidence of nitrogen fixation activity in this area (Raimbault and Garcia, 2007), it is tempting to hypothesize that these colonial PE picocyanobacteria could be nitrogen-fixing. However, Raimbault and Garcia (2007) showed that important nitrogen fixation was also observed in the center of the gyre and in the Chile upwelling where very few colonies were observed. Furthermore, small cyanobacteria having the capacity to fix nitrogen do not seem to form colonies (Zehr et al., 2001). Their morphotype (spherical 3-10 $\mu \mathrm{m}$ cells) has been rarely observed in our samples (data not shown). Alternatively, colony formation could be an adaptation to the structure of the predator community in this region, such as the higher dinoflagellates 


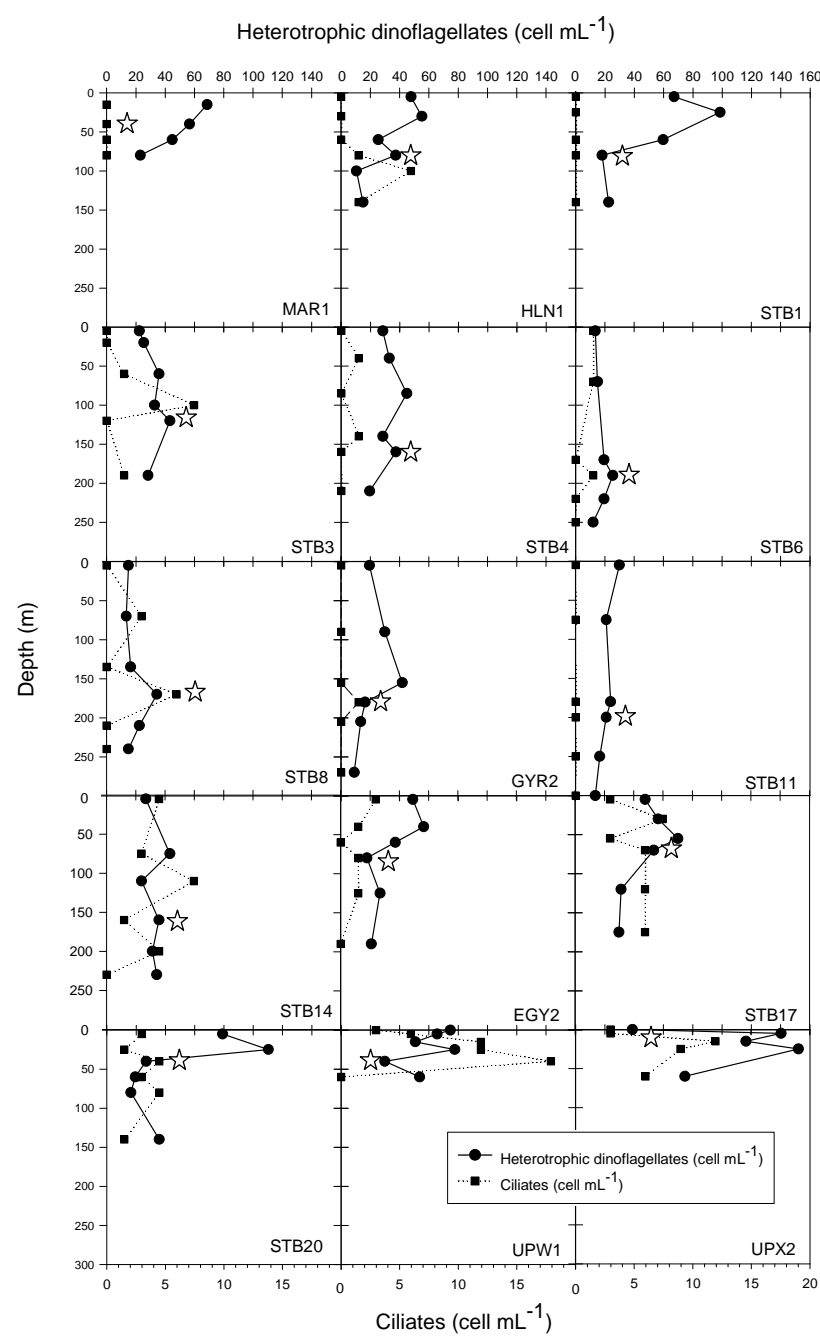

Fig. 10. Vertical profiles of concentration (cell $\left.\mathrm{mL}^{-1}\right)$ of total heterotrophic dinoflagellates (solid line) and ciliates (dotted line). Stars indicate the depth of chlorophyll maximum.

to ciliates ratio. Indeed, cells forming colonies could take advantage of the positive aspects of increased size, in particular lower grazing pressure, without paying the full cost of decreased metabolism and reduced growth which is associated with large individual cell size (Nielsen, 2006). In the light of our observations, it could be interesting to extend counts of colonial picocyanobacteria to other oceanic regions in order to better understand how this fraction varies with oceanographic conditions.

The present study is consistent with estimates by Ras et al. (2007) based on HPLC pigment data and assumptions concerning the size range of different taxonomic groups (Claustre, 1994; Vidussi et al., 2001). They found that the contribution of picophytoplankton (in terms of percentage of total chlorophyll $a$ ) was the highest in the gyre itself and east of gyre, while nanophytoplankton dominated in the HNLC zone and the Chile upwelling. However, their method tends to underestimate the contribution of picophytoplank- ton and to overestimate the contribution of macrophytoplankton. For example, they only took into account for the picoplankton size group pigments characterizing cyanobacteria and Chlorophyta. However, Prymnesiophyceae may also contribute significantly to picoeukaryotic population (MoonVan Der Staay et al., 2001; Not et al., 2005). Indeed, Prymnesiophyceae cells characterized by two chloroplasts were observed in our DAPI samples (data not shown). Conversely, Ras et al. (2007) include pigments of dinoflagellates and diatoms in the microplankton size range (20-200 $\mu \mathrm{m})$, while many dinoflagellates and some diatoms smaller than $20 \mu \mathrm{m}$ (data not shown) have been detected along the South-East Pacific transect, as observed previously along $110^{\circ} \mathrm{W}$ (Hardy et al., 1996). Therefore, the contribution of microphytoplankton could be overestimated.

During the BIOSOPE cruise, Gómez et al. (2007) found dinoflagellate abundance always lower than 1 cell $\mathrm{mL}^{-1}$, except at station 20 where a bloom of dinoflagellates was observed ( $\sim 4$ cell $\mathrm{mL}^{-1}$ between surface and $5 \mathrm{~m}$ depth), and at station UPW $\left(\sim 2\right.$ cell $\left.\mathrm{mL}^{-1}\right)$. These counts from acidified lugol's fixed samples are much lower than ours (Table 1). These differences could originate from differences in the size of the dinoflagellates that were counted in these two studies. We counted dinoflagellates which were between $5 \mu \mathrm{m}$ and $50 \mu \mathrm{m}$ in diameter while Gómez et al. (2007) only counted dinoflagellates larger than $15 \mu \mathrm{m}$. Hardy et al. (1996) showed that dinoflagellates larger than $20 \mu \mathrm{m}$ accounted only for 10 to $30 \%$ of total dinoflagellates in the Pacific gyre. In our samples (data not shown), the contribution of dinoflagellates larger than $15 \mu \mathrm{m}$ to total dinoflagellates in terms of abundances was below $1 \%$ near the Marquesas Islands, $1 \%$ in the upwelling zone, $2 \%$ in the HNLC zone and around the station EGY, and reached a maximum of 3\% at station ST20 where a bloom was observed by Gómez et al. (2007).

Globally, the abundance of dinoflagellates (Fig. 9) decreased towards the hyper-oligotrophic zone and increased towards the mesotrophic and eutrophic zones. This is in agreement with Leterme et al. (2006) who showed that the dinoflagellate abundances increased with trophic status in the NE Atlantic Ocean. The observed increase in heterotrophic dinoflagellates contribution with depth is coherent with previous observations in the Equatorial Pacific (Chavez et al., 1990). Heterotrophic dinoflagellates were always much more abundant than ciliates as shown previously in the Sargasso Sea (Lessard and Murrell, 1996) and the North-East Equatorial Pacific (Yang et al., 2004). Although it is generally admitted that heterotrophic nanoflagellates are the major grazers of picoplankton (Mackey et al., 2002; Sato et al., 2007), predation by heterotrophic dinoflagellates could also be important (Sanders et al., 2000; Sherr et al., 1991).

Green fluorescing dinoflagellates were initially observed by Shapiro et al. (1989) in the North-West Atlantic, but little reported since then. Recently, Tang and Dobbs (2007) showed that green autofluorescence is a common feature 
of dinoflagellates, diatoms, green algae, cyanobacteria and raphidophytes. They observed that this green autofluorescence is stronger in fixed cells, not stable over time, and that its intensity varies with organisms (the strongest signal is observed for dinoflagellates). Shapiro et al. (1989) found that green fluorescing dinoflagellates could contribute from 4 to $100 \%$ to heterotrophic dinoflagellates while Chavez et al. (1990) found that in the Equatorial Pacific, 32\% of heterotrophic dinoflagellates on average produced bright green fluorescence. The data reported here (maximal concentrations in excess of 60 cell $\mathrm{mL}^{-1}$ and maximum contribution up to $50 \%$, Fig. 9) are in agreement with these previous studies. The origin of this bright green fluorescence (Fig. 3c) still remains intriguing. Shapiro et al. (1989) hypothesized that it could be due to a flavoprotein. The isolation by Fujita et al. (2005) of a flavoprotein from the green-fluorescing flagellum of the brown alga Scytosiphon lomentaria lends support to this hypothesis. Kim et al. (2004) showed that the infection of the thecate dinoflagellate Gonyaulax spinifera by Amoebophrya, a parasitic dinoflagellate, induces a bright green autofluorescence in infected cells. This fluorescence is, however, much more localised than in the green dinoflagellates observed in our samples (Fig. 3c). Another attractive possibility could be the presence of a cytoplasmic green fluorescing protein (GFP, Wilson and Hastings, 1998).

Ciliate abundances reported here (Table 1) are comparable to those reported from other similar marine systems ranging from oligotrophic to eutrophic (Beers et al., 1980; Leakey et al., 1996; Lessard and Murrell, 1996; Yang et al., 2004). Focusing only on tintinnid ciliates, Dolan et al. (2007) observed during the BIOSOPE cruise much lower concentrations ranging from 0.002 and 0.04 cell $\mathrm{mL}^{-1}$ between 5 and $300 \mathrm{~m}$. However, tintinnids generally account only for 5$10 \%$ of all ciliates (Dolan and Marrasé, 1995). Comparing our data with values from Table 2 of Dolan et al. (2007) results in a proportion of tintinnids $(0.05 \%)$ smaller, for example, than in the Catalan Sea (Dolan and Marrasé, 1995). However, maxima and minima of tintinnid and total ciliates occurred simultaneously, in the upwelling and in the gyre, respectively.

The distribution pattern of ciliates (Fig. 11) agrees with previous observations in the North Western Indian Ocean (Leakey et al., 1996) where the lowest abundances were observed in oligotrophic waters and the highest in the most productive waters. The different patterns of vertical distribution of ciliates observed in the present study could be explained by the fact that no distinction has been made between the different types of ciliates (mixotrophic and heterotrophic ciliates). In the Catalan Sea, the distribution of heterotrophic ciliate is closely related to the DCM while mixotrophic ciliates display a more complicated vertical pattern and their distribution may vary from system to system (Dolan and Marrasé, 1995).

Nano-ciliates $(<20 \mu \mathrm{m})$ have been identified as potentially important grazers of picoplankton (Sherr and Sherr, 1987;

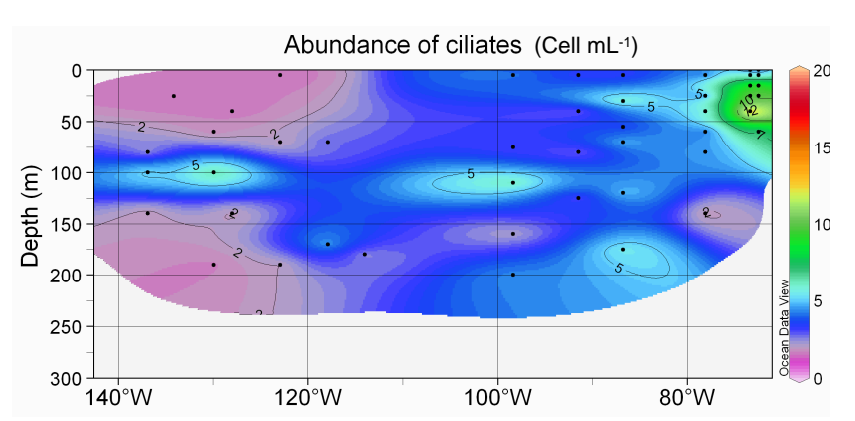

Fig. 11. Abundance of ciliates (cell $\mathrm{mL}^{-1}$ ). Legend as in Fig. 5.

Sherr et al., 1991) and account in general from 50 to $95 \%$ of total ciliates in a variety of marine ecosystems (Beers et al., 1980; Montagnes et al., 1988; Yang et al., 2004). However, in our study, we observed very few nanociliates as the size of the majority of ciliates felled into a $50-100 \mu \mathrm{m}$ range (data not shown). That could be explained by the fixation method used in our study: Leakey et al. (1994) demonstrated that the use of glutaraldehyde as fixative could lead to a loss of cells as high as $70 \%$ among aloricate ciliates relative to lugol's iodine while tintinnid numbers did not vary significantly between fixative treatments. However, Dolan and Marrasé (1995), observed only $8 \%$ of nanociliates in the Catalan Sea in June 1993 while lugol's iodine was used as fixative.

In conclusion, although assessing the abundance of the different microbial groups by DAPI microscopy is slow and labour-intensive and despite some cell loss following longterm sample storage, the present data set highlights some characteristics of the microbial community in the South-East Pacific Ocean that have escaped more rapid techniques such as flow cytometry. This includes in particular the importance of colonial PE containing picocyanobacteria in the HNLC area and the large contribution of green fluorescing dinoflagellates in some regions, such as between the gyre and the coast of South America.

Acknowledgements. D. Tailliez and C. Bournot are warmly thanked for their efficient help in CTD rosette management and data processing. D. Marie, M. Viprey and L. Garczarek are acknowledged for their help during the cruise. This is a contribution to the BIOSOPE project (LEFE-CYBER program). This research was funded by the Centre National de la Recherche Scientifique (CNRS), the Institut des Sciences de l'Univers (INSU), the Centre National d'Etudes Spatiales (CNES), the European Space Agency (ESA), the National Aeronautics and Space Administration (NASA) and the Natural Sciences and Engineering Research Council of Canada (NSERC). Additional funds were provided by the ANR Biodiversity project PICOFUNPAC. S. Masquelier was supported by a doctoral fellowship (BFR05/027) from the Ministère de la Culture, de l'Enseignement Supérieur et de la Recherche of Luxembourg.

Edited by: M. Dai 


\section{References}

Azam, F., Fenchel, T., Field, J. G., Gray, J. S., Meyer-Reil, L. A., and Thingstad, F.: The ecological role of water column microbes in the sea, Mar. Ecol.-Prog. Ser., 10, 257-263, 1983.

Beers, J. R., Reid, M. H., and Stewart, G. L.: Microplankton population structure in Southern California nearshore waters in late spring, Mar. Biol., 60, 209-226, 1980.

Campbell, L., Liu, H. B., Nolla, H. A., and Vaulot, D.: Annual variability of phytoplankton and bacteria in the subtropical North Pacific Ocean at station Aloha during the 1991-1994 ENSO event, Deep-Sea Res. I, 44, 167-192, 1997.

Capone, D. G., Zehr, J. P., Paerl, H. W., Bergman, B., and Carpenter, E. J.: Trichodesmium, a globally significant marine cyanobacterium, Science, 276, 1221-1229 1997.

Chavez, F. P., Buck, K. R., and Barber, R. T.: Phytoplankton taxa in relation to primary production in the Equatorial Pacific, DeepSea Res. II, 37, 1733-1752, 1990.

Christaki, U., Courties, C., Karayanni, H., Giannakourou, A., Maravelias, C., Kormas, K. A., and Lebaron, P.: Dynamic characteristics of Prochlorococcus and Synechococcus consumption by bacterivorous nanoflagellates, Microb. Ecol., 43, 341-352, 2002.

Claustre, H.: The trophic status of various oceanic provinces as revealed by phytoplankton pigment signatures, Limnol. Oceanogr., 39, 1206-1210, 1994.

Claustre, H., Huot, Y., Obernosterer, I., Gentili, B., Tailliez, D., and Lewis, M.: Gross community production and metabolic balance in the South Pacific Gyre, using a non intrusive bio-optical method, Biogeosciences Discuss., 4, 3089-3121, 2007,

http://www.biogeosciences-discuss.net/4/3089/2007/.

Claustre, H., Sciandra, A., and Vaulot, D.: Introduction to the special section: Bio-optical and biogeochemical conditions in the South East Pacific in late 2004 - the BIOSOPE cruise, Biogeosciences Discuss., 5, 605-640, 2008,

http://www.biogeosciences-discuss.net/5/605/2008/.

Courties, C., Vaquer, A., Trousselier, M., Lautier, J., ChrétiennotDinet, M.-J., Neveux, J., Machado, C., and Claustre, H.: Smallest eukaryotic organism, Nature, 370, 255, 1994.

Dolan, J. R. and Marrasé, C.: Planktonic ciliate distribution relative to a deep chlorophyll maximum: Catalan Sea. N.W. Mediterranean, June 1993, Deep-Sea Res. I, 42, 1965-1987, 1995.

Dolan, J. R., Ritchie, M. E., and Ras, J.: The "neutral" community structure of planktonic herbivores, tintinnid ciliates of the microzooplankton, across the SE Tropical Pacific Ocean, Biogeosciences, 4, 297-310, 2007,

http://www.biogeosciences.net/4/297/2007/.

Fenchel, T.: Ecology of heterotrophic microflagellates. II. Bioenergetics and growth, Mar. Ecol.-Prog. Ser., 8, 225-231, 1982.

Fujita, S., Iseki, M., Yoshikawa, S., Makino, Y., Watanabe, M., Motomura, T., Kawai, H., and Murakami, A.: Identification and characterization of a fluorescent flagellar protein from the brown alga Scytosiphon lomentaria (Scytosiphonales, Phaeophyceae): a flavoprotein homologous to old yellow enzyme, Eur. J. Phycol., 40, 159-167, 2005.

Gómez, F., Claustre, H., Raimbault, P., and Souissi, S.: Two HighNutrient Low-Chlorophyll phytoplankton assemblages: The tropical central Pacific and the offshore Perú-Chile current, Biogeosciences, 4, 1101-1113, 2007, http://www.biogeosciences.net/4/1101/2007/.

Graham, L. and Wilcox, L.: Algae, Prentice Hall, Inc. Upper Saddle
River, NJ, 630 pp., 2000.

Grob, C., Ulloa, O., Claustre, H., Huot, Y., Alarcon, G., and Marie, D.: Contribution of picoplankton to the total particulate organic carbon concentration in the Eastern South Pacific, Biogeosciences, 4, 837-852, 2007, http://www.biogeosciences.net/4/837/2007/.

Gundersen, K., Bratbak, G., and Heldal, M.: Factors influencing the loss of bacteria in preserved seawater samples, Mar. Ecol.-Prog. Ser., 137, 305-307, 1996.

Hagström, Azam, F., Andersson, A., Wikner, J., and Rassoulzadegan, F.: Microbial loop in an oligotrophic pelagic marine ecosystem: possible roles of cyanobacteria and nanoflagellates in the organic fluxes, Mar. Ecol.-Prog. Ser., 49, 171-178, 1988.

Hardy, J., Hanneman, A., Behrenfeld, M., and Horner, R.: Environmental biogeography of near-surface phytoplankton in the Southeast Pacific Ocean, Deep-Sea Res. I, 43, 1647-1659, 1996.

Kim, S., Park, M. G., Yih, W., and Coats, D. W.: Infection of the bloom-forming thecate dinoflagellates Alexandrium affine and Gonyaulax spinifera by two strains of Amoebophrya (Dinophyta), J. Phycol., 40, 815-822, 2004.

Le Gall, F., Marie, D., Garczarek, L., Viprey, M., and Vaulot, D.: Picoplankton diversity in the South East Pacific from cultures, Biogeosciences, 5, 203-214, 2008, http://www.biogeosciences.net/5/203/2008/.

Leakey, R. J. G., Burkill, P. H., and Sleigh, M. A.: A comparison of fixatives for the estimation of abundance and biovolume of marine planktonic ciliate populations, J. Plankton Res., 16, 375389, 1994.

Leakey, R. J. G., Burkill, P. H., and Sleigh, M. A.: Planktonic ciliates in the Northwestern Indian ocean: their abundance and biomass in waters of contrasting productivity, J. Plankton Res., 18, 1063-1071, 1996.

Lessard, E. J. and Murrell, M. C.: Distribution, abundance and size composition of heterotrophic dinoflagellates and ciliates in the Sargasso Sea near Bermuda, Deep-Sea Res. I, 43, 1045-1065, 1996.

Leterme, S. C., Seuront, L., and Edwards, M.: Differential contribution of diatoms and dinoflagellates to phytoplankton biomass in the NE Atlantic Ocean and the North Sea, Mar. Ecol.-Prog. Ser., 312, 57-65, 2006.

Mackey, D. J., Blanchot, J., Higgins, H. W., and Neveux, J.: Phytoplankton abundances and community structure in the Equatorial Pacific, Deep-Sea Res. II, 49, 2561-2582, 2002.

Marañón, E., Holligan, P. M., Barciela, R., González, N., Mouriño, B., Pazó, M. J., and Varela, M.: Patterns of phytoplankton size structure and productivity in contrasting open-ocean environments, Mar. Ecol.-Prog. Ser., 216, 43-56, 2001.

Montagnes, D. J. S., Lynn, D. H., Roff, J. C., and Taylor, W. D.: The annual cycle of heterotrophic planktonic ciliates in the waters surrounding the isles of shoals, Gulf of Maine: an assessment of their trophic role, Mar. Biol., 99, 21-30, 1988.

Moon-van der Staay, S. Y., De Wachter, R., and Vaulot, D.: Oceanic $18 \mathrm{~S}$ rDNA sequences from picoplankton reveal unsuspected eukaryotic diversity, Nature, 409, 607-610, 2001.

Morel, A., Gentili, B., Claustre, H., Babin, M., Bricaud, A., Ras, J., and Tieche, F.: Optical properties of the "clearest" natural waters, Limnol. Oceanogr., 52, 217-229, 2007.

Nielsen, S. L.: Size-dependent growth rates in eukaryotic and prokaryotic algae exemplified by green algae and cyanobacte- 
ria: Comparisons between unicells and colonial growth forms, J. Plankton Res., 28, 489-498, 2006.

Not, F., Massana, R., Latasa, M., Marie, D., Colson, C., Eikrem, W., Pedrós-Alió, C., Vaulot, D., and Simon, N.: Late summer community composition and abundance of photosynthetic picoeukaryotes in Norvegian and Barents Seas, Limnol. Oceanogr., 50, 1677-1686, 2005.

Paerl, H. W.: Marine plankton, The ecology of cyanobacteria: Their diversity in time and space, Kluwer Academic Publishers, Dordrecht, The Netherlands, 121-148, 2000.

Partensky, F., Hess, W. R., and Vaulot, D.: Prochlorococcus, a marine photosynthetic prokaryote of global significance, Microb. Mol. Biol. R., 63, 106-127, 1999.

Pérez, V., Fernández, E., Marañón, E., Morán, X. A. G. and Zubkovc, M. V.: Vertical distribution of phytoplankton biomass, production and growth in the Atlantic subtropical gyres, DeepSea Res. I, 53, 1616-1634, 2006.

Porter, K. G. and Feig, Y. S.: The use of DAPI for identifying and counting aquatic microflora, Limnol. Oceanogr., 25, 943-948, 1980.

Putland, J. and Rivkin, R.: Influence of storage mode and duration on the microscopic enumeration of Synechococcus from a cold coastal ocean environment, Aquat. Microb. Ecol., 17, 191-199, 1999.

Raimbault, P. and Garcia, N.: Carbon and nitrogen uptake in the South Pacific Ocean: Evidence for efficient dinitrogen fixation and regenerated production leading to large accumulation of dissolved organic matter in nitrogen-depleted waters, Biogeosciences Discuss., 4, 3531-3579, 2007,

http://www.biogeosciences-discuss.net/4/3531/2007/.

Raimbault, P., Garcia, N., and Cerutti, F.: Distribution of inorganic and organic nutrients in the South Pacific Ocean-evidence for long-term accumulation of organic matter in nitrogen-depleted waters, Biogeosciences Discuss., 4, 3041-3087, 2007, http://www.biogeosciences-discuss.net/4/3041/2007/.

Ras, J., Uitz, J. and Claustre, H.: Spatial variability of phytoplankton pigment distribution in the South East Pacific, Biogeosciences Discuss., 4, 3409-3451, 2007,

http://www.biogeosciences-discuss.net/4/3409/2007/.

Raven, J. A.: The twelfth Tansley lecture. Small is beautiful: The picophytoplankton, Funct. Ecol., 12, 503-513, 1998.

Sanders, R. W., Berninger, U. G., Lim, E. L., Kemp, P. F., and Caron, D. A.: Heterotrophic and mixotrophic nanoplankton predation on picoplankton in the Sargasso Sea and on Georges Bank, Mar. Ecol.-Prog. Ser., 192, 103-118, 2000.
Sato, M., Yoshikawa, T., Takeda, S., and Furuya, K.: Application of the size-fractionation method to simultaneous estimation of clearance rates by heterotrophic flagellates and ciliates of picoand nanophytoplankton, J. Exp. Mar. Biol. Ecol., 349, 334-343, 2007.

Schlitzer, R.: ODV software, http://www.awi-bremerhaven.de/ GEO/ODV, 2003.

Shapiro, L. P., Haugen, E. M., and Carpenter, E. J.: Occurrence and abundance of green-fluorescing dinoflagellates in surface waters of the Northwest Atlantic and Northeast Pacific Oceans, J. Phycol., 25, 189-191, 1989.

Sherr, B. F. and Sherr, E. B.: High rates of consumption of bacteria by pelagic ciliates, Nature, 325, 710-711, 1987.

Sherr, E. B. and Sherr, B. F.: Marine microbes an overview, in: Microbial Ecology of the Oceans, edited by: Kirchman, D. L., New York, Willey-Liss, Inc., 13-46, 2000.

Sherr, E. B., Sherr, B. F., and Wheeler, P. A.: Distribution of coccoid cyanobacteria and small eukaryotic phytoplankton in the upwelling ecosystem off the Oregon coast during 2001 and 2002, Deep-Sea Res. II, 52, 317-330, 2005.

Sherr, E. F., Sherr, B. F., and McDaniel, J.: Clearance rates of $<6 \mu \mathrm{m}$ fluorescently labeled algae (FLA) by estuarine protozoa: Potential grazing impact of flagellates and ciliates, Mar. Ecol. Prog. Ser., 69, 81-92, 1991.

Sieburth, J. M., Smetacek, V., and Lenz, J.: Pelagic ecosystem structure: Heterotrophic compartments of the plankton and their relationship to plankton size fractions, Limnol Oceanogr, 23, 1256-1263, 1978.

Tang, Y. Z. and Dobbs, F. C.: Green autofluorescence in dinoflagellates, diatoms, and other microalgae and its implications for vital staining and morphological studies, Appl. Environ. Microbiol., 73, 2306-2313, 2007.

Vidussi, F., Claustre, H., Manca, B. B., Luchetta, A., and Marty, J. C.: Phytoplankton pigment distribution in relation to upper thermocline circulation in the Eastern Mediterranean Sea during winter, J. Geophys. Res., 106, 19939-19956, 2001.

Wilson, T. and Hastings, J. W.: Bioluminescence, Annu. Rev. Cell Dev. Bi., 14, 197-230, 1998.

Yang, E. J., Choi, J. K., and Hyun, J. H.: Distribution and structure of heterotrophic protist communities in the Northeast Equatorial Pacific Ocean, Mar. Biol., 146, 1-15, 2004.

Zehr, J. P., Waterbury, J. B., Turner, P. J., Montoya, J. P., Omoregie, E., Steward, G. F., Hansen, A., and Karl, D. M.: Unicellular cyanobacteria fix $\mathrm{N}_{2}$ in the subtropical North Pacific Ocean, Nature, 412, 635-638, 2001. 